\title{
Physiological Characteristics of a New Thermophilic Obligately Chemolithotrophic Thiobacillus Species, Thiobacillus tepidarius
}

\author{
ANN P. WOOD AND DON P. KELLY* \\ Department of Environmental Sciences, University of Warwick, Coventry CV4 7AL, United Kingdom
}

\begin{abstract}
We describe a new Thiobacillus species which is a gram-negative, motile, rod-shaped organism having polar flagella. The optimum growth temperature is 43 to $45^{\circ} \mathrm{C}$, and the optimum pH range is 6.0 to 7.5. This organism is obligately chemolithotrophic and autotrophic and has ribulose bisphosphate carboxylase activity. It is able to oxidize thiosulfate, trithionate, tetrathionate, hexathionate, heptathionate, sulfur, and sulfide, but is not able to use sulfite, thiocyanate, or dithionate for growth. In batch culture it converts thiosulfate to tetrathionate during or before growth. It has both rhodanese and thiosulfate-oxidizing enzyme activites. It does not grow anaerobically with nitrate or nitrous oxide on either thiosulfate or tetrathionate. The guanine-pluscytosine content of its deoxyribonucleic acid is $66.6 \mathrm{~mol} \%$, and it contains ubiquinone Q-8 in its respiratory chain. The organism is named Thiobacillus tepidarius sp. nov. The type strain is strain DSM 3134, which has been deposited in the Deutsche Sammlung von Mikroorganismen, Göttingen, Federal Republic of Germany.
\end{abstract}

Although thermophilic, acidophilic strains belonging to the genus Thiobacillus have been reported in the past, no thermophilic species are currently known to be in culture collections, and no species has been properly described. We isolated a novel obligately chemolithotrophic, moderately thermophilic Thiobacillus species that is distinct from all species described previously. It differs from previously reported thermophiles in growing only around neutral $\mathrm{pH}$ and is unlike any other organism previously described except perhaps Sulfomonas sp. strain no. 3 of Czurda (1).

We named this organism Thiobacillus tepidarius, and it is 1 of the 13 species of Thiobacillus recognized in Bergey's Manual of Systematic Bacteriology, 1st ed. (D. P. Kelly and A. P. Harrison, in press).

\section{MATERIALS AND METHODS}

Isolation of the organism. Samples of water from the inflow of the Great Bath (in the Roman baths at Bath, Avon, United Kingdom) having a temperature of $43^{\circ} \mathrm{C}$ and a $\mathrm{pH}$ of 7.3 were inoculated into liquid medium containing either thiosulfate $(20 \mathrm{mM})$ or methylammonium chloride $(10 \mathrm{mM})$ or both and were incubated in $250-\mathrm{ml}$ flasks shaken in air at $50^{\circ} \mathrm{C}$. The most successful culture, which was obtained by growing the organism on methylammonium plus thiosulfate, was subcultured into medium containing methylammonium and $5 \mathrm{mM}$ $\mathrm{NaHCO}_{3}$. The resulting culture was then plated onto thiosulfate agar medium and incubated at $50^{\circ} \mathrm{C}$ in gas jars with an enhanced $\mathrm{CO}_{2}$ atmosphere (5\%, vol/vol). Single-colony isolations were made, and the two most promising isolates were inoculated into liquid media containing either thiosulfate or methylammonium with or without $\mathrm{NaHCO}_{3}$. At this stage no growth was obtained on methylammonium, but growth on thiosulfate was good. One of the single-colony isolates was studied further and characterized.

Culture conditions. Thiobacillus tepidarius was isolated by using liquid medium containing (per liter) $4.0 \mathrm{~g}$ of $\mathrm{K}_{2} \mathrm{HPO}_{4}$, $4.0 \mathrm{~g}$ of $\mathrm{KH}_{2} \mathrm{PO}_{4}, 0.4 \mathrm{~g}$ of $\mathrm{NH}_{4} \mathrm{Cl}, 0.8 \mathrm{~g}$ of $\mathrm{MgSO}_{4} \cdot 7 \mathrm{H}_{2} \mathrm{O}$, and $10 \mathrm{ml}$ of a trace metal solution (8). To vary the $\mathrm{pH}$ in growth experiments in batch cultures, the ratio of the phosphates

\footnotetext{
* Corresponding author.
}

was altered, but the same overall molar concentration of phosphates was maintained. The phosphates were sterilized separately and aseptically mixed with the other medium components after autoclaving and cooling. We made agar slants and plates containing the medium described above supplemented with $10 \mathrm{~g}$ of Bacto-agar (Difco Laboratories) per liter and $2 \mathrm{ml}$ of saturated aqueous bromocresol purple per liter. The energy source supplied was either $20 \mathrm{mM}$ $\mathrm{Na}_{2} \mathrm{~S}_{2} \mathrm{O}_{3} \cdot 5 \mathrm{H}_{2} \mathrm{O}$ or $10 \mathrm{mM} \mathrm{K} 2 \mathrm{~S}_{4} \mathrm{O}_{6}$. Once purified, the organism was maintained on agar slants containing tetrathionate medium.

Agar medium supplemented with either Oxoid nutrient broth (1.3 g/liter) or thiosulfate or both was used for plating dilutions of cultures to check for contaminants. To determine heterotrophic potential, the following agar media were used: Lab M nutrient agar $(2.8 \%$, wt/vol) and Oxoid nutrient broth $(0.325 \%, \mathrm{wt} / \mathrm{vol})$ containing Bacto-agar $(1.5 \%, \mathrm{wt} / \mathrm{vol})$ with and without glucose $(0.5 \%, \mathrm{wt} / \mathrm{vol})$.

Growth experiments. Inoculum cultures $(100 \mathrm{ml})$ for experiments were grown routinely on $20 \mathrm{mM}$ thiosulfate medium that was inoculated from thiosulfate slants and shaken in 250-ml Erlenmeyer flasks. When $\mathrm{NaHCO}_{3}$ was added as the $\mathrm{CO}_{2}$ supply, the cultures were grown in Quickfit flasks fitted with Suba Seal vaccine stoppers. Inocula $(10 \%$, wt $/ \mathrm{vol})$ from these fully grown cultures were added to $100 \mathrm{ml}$ of test medium and shaken at the appropriate temperature on a Gallenkamp orbital incubator. Samples $(2$ to $5 \mathrm{ml}$ ) were removed at intervals for analysis. Growth was monitored by measuring culture absorbance at $440 \mathrm{~nm}$, which was converted to dry weight (in grams per liter) by referring to a calibration curve prepared for suspensions of organisms dried to constant weight at $105^{\circ} \mathrm{C}$. Thiosulfate, tetrathionate, and other polythionates were assayed by the cyanolysis method (5).

Anaerobic growth was tested at $43^{\circ} \mathrm{C}$ in $100-$ or $150-\mathrm{ml}$ bottles completely filled with medium $(\mathrm{pH} 7.0)$ supplemented with $33 \mathrm{mM} \mathrm{KNO}_{3}$.

pH-controlled growth experiments. Batch cultures (1 liter) were grown in an LH Engineering series $500 \mathrm{III}$ fermentor. Initially, the $\mathrm{pH}$ was controlled to 7.0 by using automatic titration with $\mathrm{Na}_{2} \mathrm{CO}_{3}$; the culture was stirred at $750 \mathrm{rpm}$ and aerated with $100 \mathrm{ml}$ of air per min. The aeration and stirrer 
TABLE 1. Effect of initial $\mathrm{pH}$ on the growth of T. tepidarius at $50^{\circ} \mathrm{C}^{a}$

\begin{tabular}{|c|c|c|c|c|c|}
\hline \multirow[t]{2}{*}{ Culture } & \multirow[t]{2}{*}{$\begin{array}{c}\text { Initial } \\
\mathrm{pH}\end{array}$} & \multirow[t]{2}{*}{$\begin{array}{c}\text { Final } \\
\mathrm{pH}\end{array}$} & \multicolumn{2}{|c|}{$\begin{array}{c}\% \text { Of initial } \mathrm{Na}_{2} \mathrm{~S}_{2} \mathrm{O}_{3} \\
(20 \mathrm{mM}) \text { remaining } \\
\text { at the end of growth } \\
\text { as: }\end{array}$} & \multirow[t]{2}{*}{$\begin{array}{l}\text { Specific } \\
\text { growth } \\
\text { rate } \\
\left(\mathrm{h}^{-1}\right)\end{array}$} \\
\hline & & & $\overline{\mathrm{S}_{2} \mathrm{O}_{3}{ }^{2-}}$ & $\mathrm{S}_{4} \mathrm{O}_{6}{ }^{2-}$ & \\
\hline 1 & 5.0 & 5.4 & 54.6 & 21.5 & $\mathrm{NG}^{b}$ \\
\hline 2 & 5.5 & 5.2 & 0 & 77.3 & 0.046 \\
\hline 3 & 5.6 & 4.9 & 0 & 62.3 & 0.053 \\
\hline 4 & 5.7 & 4.9 & 1.8 & 67.1 & 0.058 \\
\hline 5 & $5.7^{c}$ & 4.8 & 13.8 & 58.0 & 0.046 \\
\hline 6 & 6.3 & 4.8 & 0.7 & 49.5 & 0.058 \\
\hline 7 & 6.4 & 5.0 & 0 & 47.5 & 0.066 \\
\hline 8 & $7.0^{c}$ & 6.5 & 7.1 & 1.6 & 0.043 \\
\hline 9 & 7.0 & 5.1 & 4.9 & 21.6 & 0.039 \\
\hline 10 & 7.7 & 5.3 & 4.2 & 8.3 & 0.020 \\
\hline 11 & 8.0 & 7.4 & 96.7 & 6.8 & NG \\
\hline 12 & 8.5 & 7.6 & 96.5 & 2.8 & NG \\
\hline 13 & $6.9^{d}$ & 5.2 & 0 & 61.0 & 0.060 \\
\hline
\end{tabular}

${ }^{a}$ Except where indicated, cultures were grown on $20 \mathrm{mM} \mathrm{Na}_{2} \mathrm{~S}_{2} \mathrm{O}_{3}$ by using inoculum cultures grown initially at $\mathrm{pH}$ 7.0. The inoculum for culture 1 came from culture 4 . The inocula for cultures 5 and 8 came from cultures 4 and 9 respectively. The inoculum for culture 13 came from culture 9 .

${ }^{b}$ NG, No growth.

$c$ The initial thiosulfate concentration was $5 \mathrm{mM}$.

${ }^{d}$ Tetrathionate was supplied at a concentration of $10 \mathrm{mM}$ in the absence of thiosulfate.

rates were increased to $300 \mathrm{ml} / \mathrm{min}$ and $1,000 \mathrm{rpm}$, respectively, when we found that these rates increased the growth rates at the higher temperatures tested. Once the temperature optimum had been determined, the culture temperature was constant while the growth rates were measured at a number of $\mathrm{pH}$ values.

Preparation of cell extracts. Cultures were harvested by centrifugation, washed once with $0.055 \mathrm{M}$ phosphate buffer ( $\mathrm{pH} 8.0$ ), centrifuged at $23,000 \times g$, and then suspended in $0.1 \mathrm{M}$ PIPES [piperazine- $N, N^{\prime}$-bis (2-ethanesulfonic acid)] buffer $(\mathrm{pH} \mathrm{7.0)}$. This cell suspension was then passed twice through a French pressure cell at $1.4 \times 10^{8} \mathrm{~Pa}$ and centrifuged at $38,000 \times g$ for $45 \mathrm{~min}$. The resultant supernatant was used to assay for rhodanese and thiosulfate-oxidizing enzymes.

Enzyme assays. The method used for the rhodanese assay was based on a previously described method (6), as was the assay used for thiosulfate-oxidizing enzyme (3). Ribulose bisphosphate carboxylase was assayed by the whole-cell procedure (7). All enzyme assays were carried out at 43 to $45^{\circ} \mathrm{C}$.

DNA base composition. The guanine-plus-cytosine $(\mathrm{G}+\mathrm{C})$ content of the deoxyribonucleic acid (DNA) was determined by the buoyant density method and was carried out by C. S. Dow.

Ubiquinone analysis. The ubiquinone fraction of the organism was isolated by acetone extraction (2) of a bacterial suspension that had been passed twice through the French pressure cell. The purified ubiquinone fraction (in hexane) was reduced almost to dryness by rapid rotary evaporation at $55^{\circ} \mathrm{C}$. The residue was dissolved in ethanol $(2 \mathrm{ml})$, and the ubiquinone was identified by comparative thin-layer chromatography. The marker compounds used were ubiquinone Q-10 (Sigma Chemical Co.) and ubiquinone Q-8 isolated from Thiobacillus denitrificans by the same procedure. Chromatograms were run with benzene on Gelman ITLC SAF or Merck DC Alufolien Kieselgel $60 \mathrm{~F}_{254}$ plates. Both of these contained a fluorescent dye which enabled direct observation of ubiquinones as dark spots under ultraviolet light ( $254 \mathrm{~nm}$ ). The $R_{f}$ values obtained were 0.78 and 0.59 for ubiquinone Q-8 and 0.38 and 0.15 for ubiquinone Q-10 on ITLC SAF and DC Alufolien Kieselgel $60 \mathrm{~F}_{254}$ plates, respectively.

\section{RESULTS}

Morphological and physiological characteristics. $T$. tepidarius cells are motile, rod shaped, and about 0.3 by 0.8 $\mu \mathrm{m}$, have polar flagellation, and contain storage polyphosphate inclusions. This organism is able to grow autotrophically on a wide range of reduced sulfur compounds, including sulfur, sulfide, thiosulfate, trithionate, tetrathionate, hexathionate, and heptathionate, but is not able to grow on dithionate, sulfite, or thiocyanate. Sulfur is deposited in colonies on thiosulfate agar but not in aerobic liquid cultures. A microscopic examination of organisms from such colonies revealed significant pleiomorphism (apparently due mainly to variable amounts of intracellular inclusions); such pleiomorphism was not seen in organisms grown in liquid cultures. T. tepidarius is not able to grow heterotrophically or as a mixotroph. Autotrophic growth appears to be explained by the presence of ribulose bisphosphate carboxylase, the activity of which was 0.2 $\mu \mathrm{mol}$ of $\mathrm{CO}_{2}$ fixed per min per mg (dry weight) in the whole-cell assay. Rhodanese and thiosulfate-oxidizing enzyme activities of 0.2 to $0.8 \mu \mathrm{mol}$ of $\mathrm{S}_{2} \mathrm{O}_{3}{ }^{2-}$ used per min per $\mathrm{mg}$ of protein were found in crude extracts. Although $T$. tepidarius can reduce nitrate to nitrite, it is not able to grow anaerobically with either nitrate or nitrous oxide.

Growth experiments. $T$. tepidarius grew on thiosulfate in media having initial $\mathrm{pH}$ values of 5.5 to 7.7 at $50^{\circ} \mathrm{C}$ (Table 1 ). Before growth started, the thiosulfate was always quantitatively converted to tetrathionate, and there was a concurrent increase in $\mathrm{pH}$. Once the $\mathrm{pH}$ had fallen to about 5.0, growth stopped. No growth occurred in medium at $\mathrm{pH} 5.0$, although some oxidation of thiosulfate was detected. Some cultures (Table 1 , cultures 4,10 , and 11) were analyzed for trithionate, but none was detected as an intermediate product.

Addition of glucose $(1 \mathrm{mM})$, yeast extract $(0.02 \%)$, or nutrient broth $(0.13 \%)$ had little effect on the growth rate of T. tepidarius on thiosulfate at $\mathrm{pH} 7.0$ and did not increase biomass. The organism was not able to grow in a liquid

TABLE 2. Temperature range for growth of $T$. tepidarius on thiosulfate $(20 \mathrm{mM})$ in batch cultures initially at $\mathrm{pH} 6.6$

\begin{tabular}{lcccc}
\hline $\begin{array}{c}\text { Temp } \\
\left({ }^{\circ} \mathrm{C}\right)\end{array}$ & $\begin{array}{c}\text { Final } \\
\mathrm{pH}\end{array}$ & $\begin{array}{c}\text { \% Of initial thiosulfate } \\
\text { remaining at the end of } \\
\text { incubation as: }\end{array}$ & $\begin{array}{c}\text { Specific } \\
\text { growth rate } \\
\left(\mathrm{h}^{-1}\right)\end{array}$ \\
\cline { 3 - 4 } & & $\mathrm{S}_{2} \mathrm{O}_{3}^{2-}$ & $\mathrm{S}_{4} \mathrm{O}_{6}{ }^{2-}$ & $\mathrm{NG}^{a}$ \\
\hline 15 & 7.2 & 9.0 & 77.0 & 0.014 \\
20 & 4.4 & 0 & 35.2 & 0.024 \\
25 & 6.1 & 0 & 45.2 & 0.048 \\
30 & 3.9 & 0.5 & 29.6 & 0.063 \\
37 & 5.1 & 0 & 39.2 & 0.055 \\
43 & 4.7 & 0 & 40.5 & 0.063 \\
50 & 4.5 & 0 & 37.2 & 0.004 \\
$52^{b}$ & $\mathrm{ND}$ & 62.5 & 31.0 & $\mathrm{NG}$ \\
55 & 6.6 & 74.7 & 12.1 & $\mathrm{NG}$ \\
$60^{d}$ & 6.6 & 107.3 & 0 & \\
\hline
\end{tabular}

${ }^{a}$ NG, No growth.

${ }^{b}$ The inoculum culture was grown at $43^{\circ} \mathrm{C}$.

$c$ ND, Not determined.

${ }^{d}$ The inoculum culture was grown at $\mathrm{pH} 7.7$. 
rutrient broth culture without thiosulfate or at $43^{\circ} \mathrm{C}$ on yeast extract $(0.02 \%)$, succinate $(10 \mathrm{mM})$, glucose $(10 \mathrm{mM})$, glutarnate $(10 \mathrm{mM})$, ribose $(10 \mathrm{mM})$, fructose $(10 \mathrm{mM})$, sucrose $(10 \mathrm{mM})$, citrate $(10 \mathrm{mM})$, acetate $(20 \mathrm{mM})$, glycolate $(30$ $\mathrm{mM})$, formate $(40 \mathrm{mM})$, methylammonium chloride $(50 \mathrm{mM})$, nutrient agar, or nutrient agar supplemented with glucose.

Using batch culture methods and media at $\mathrm{pH} 6.6$ to 6.8 , we determined the temperature range for growth (Table 2). The limits were 20 to $52^{\circ} \mathrm{C}$, with a broad optimum range of 37 to $50^{\circ} \mathrm{C}$. Oxidation of thiosulfate to tetrathionate was possible at $15^{\circ} \mathrm{C}$ (without growth) but not at 55 or $60^{\circ} \mathrm{C}$.

Additional studies were carried out by using a fermentor with automatic $\mathrm{pH}$ control so that batch cultures could be maintained under constant environmental conditions for precise determination of optimum temperature and $\mathrm{pH}$ values for growth. In these studies we used tetrathionate as the substrate since production of tetrathionate from thiosulfate results in a $\mathrm{pH}$ increase which would have complicated the control of $\mathrm{pH}$ unnecessarily. The optimum temperature for growth (Fig. 1) was 43 to $45^{\circ} \mathrm{C}$. Cultures controlled at this optimum temperature were used to measure growth rates over a range of $\mathrm{pH}$ values (Fig. 1). The $\mathrm{pH}$ optimum covered a broad range ( $\mathrm{pH} 6.0$ to 7.5 ).

Trithionate $(6.5 \mathrm{mM})$ was supplied to a fully grown tetrathionate culture at $45^{\circ} \mathrm{C}$ and $\mathrm{pH} 7.2$. This substrate disappeared from the medium with a half-life of $30 \mathrm{~min}$ and without any detectable sulfur, thiosulfate, or tetrathionate being produced.

Anaerobic growth on tetrathionate was not observed although about one-half of the nitrate supplied was converted to nitrite.

Molar growth yields. When grown at a dilution rate of 0.4 $\mathrm{h}^{-1}$ in a substrate-limited chemostat culture, $T$. tepidarius gave yields of 10.2 and $17.2 \mathrm{~g}$ (dry weight per mol of substrate oxidized) on thiosulfate and tetrathionate, respectively (Wood and Kelly, submitted for publication).

DNA base composition. Triplicate estimations by the buoyant density method indicated that the $G+C$ content of the DNA was $66.6 \pm 0.5 \mathrm{~mol} \%$.

Ubiquinone content. The mobility of the ubiquinone isolated from $T$. tepidarius indicated that it was ubiquinone Q-8 (based on the mobilities of the ubiquinone Q-8 and Q-10 markers).

\section{DISCUSSION}

The thermophile described above belongs in the genus Thiobacillus since it is a gram-negative, motile, rod-shaped organism which obtains energy by oxidizing reduced inorganic sulfur compounds. It is similar to Thiobacillus thioparus, Thiobacillus neapolitanus, Thiobacillus thiooxidans, and Thiobacillus denitrificans in that it is obligately chemolithotrophic and autotrophic and contains ubiquinone Q-8 (4), but it differs from all of the other species currently known to be in pure culture in that it is thermophilic. The $\mathrm{G}+\mathrm{C}$ content of its DNA $(66.6 \mathrm{~mol} \%)$ indicates that it is significantly different genetically from the type species, T. thioparus $(62 \mathrm{~mol} \%)$ and from $T$. neapolitanus $(56 \mathrm{~mol} \%)$, although because of its ability to oxidize and grow on sulfur compounds it closely resembles T. neapolitanus. We propose the name Thiobacillus tepidarius $\mathrm{sp}$. nov. for this new thermophile.

Description of Thiobacillus tepidarius. The description of $T$. tepidarius (tep.i.dar'i.us. L.n. tepidarium a warm bath fed by natural thermal water; M.L. adj. tepidarius warmbathing) given below is based on one strain (the type strain).

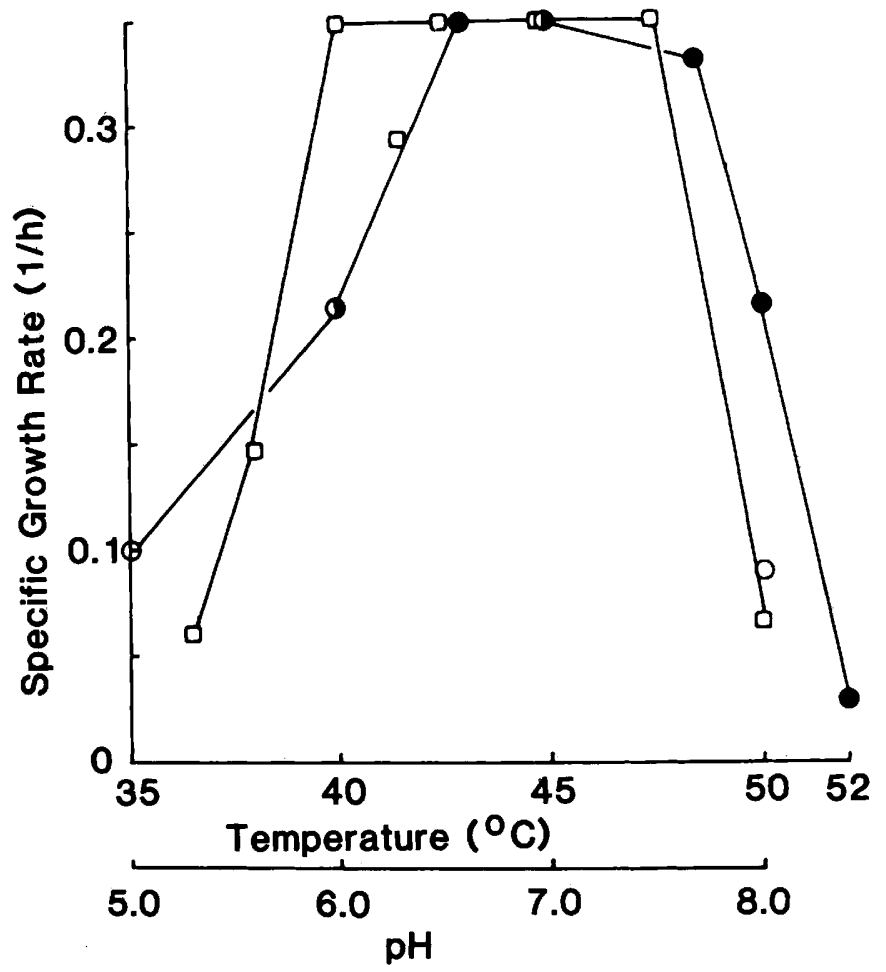

FIG. 1. Temperature and $\mathrm{pH}$ profiles for autotrophic growth of $T$. tepidarius $\mathrm{sp}$. nov. on tetrathionate. The specific growth rates are shown for a range of temperatures with aeration of $100 \mathrm{ml} / \mathrm{min}$ and stirring at $750 \mathrm{rpm}(O)$ or with aeration of $300 \mathrm{ml} / \mathrm{min}$ and stirring at $1000 \mathrm{rpm}()_{)}$at $\mathrm{pH} 7.0$ and for a range of $\mathrm{pH}$ values $(\square)$ at $43^{\circ} \mathrm{C}$.

Cells are gram-negative, motile, rod shaped, and 0.2 to 0.4 by 0.6 to $1.0 \mu \mathrm{m}$, with polar flagella that are three to five times the length of the cell. Cells contain storage polyphosphate inclusions. This organism is obligately chemolithotrophic and autotrophic, using the oxidation of thiosulfate, trithionate, tetrathionate, hexathionate, heptathionate, sulfur, and sulfide for growth. Thiosulfate is initially quantitatively converted to tetrathionate before growth proceeds. Carbon dioxide is fixed by means of ribulose bisphosphate carboxylase. On agar medium containing thiosulfate, colonies are creamy white, opaque, and up to $2 \mathrm{~mm}$ in diameter. The temperature for optimum growth is 43 to $45^{\circ} \mathrm{C}$. The $\mathrm{pH}$ for optimum growth is $\mathrm{pH} 6.0$ to 7.5. Nitrate is reduced to nitrite, but growth does not occur with either nitrate or nitrous oxide. The DNA contains $66.6 \mathrm{~mol} \% \mathrm{G}+\mathrm{C}$. Ubiquinone $\mathrm{Q}-8$ is present in the respiratory chain. The organism was isolated from water at the Roman baths, Bath, Avon, United Kingdom. The type strain has been deposited with the Deutsche Sammlung von Mikroorganismen, Göttingen, Federal Republic of Germany, as strain DSM 3134.

\section{ACKNOWLEDGMENTS}

This work was entirely financed by Biogen S.A., Geneva, Switzerland.

We are grateful to Julian Davies for his encouragement and support. We are indebted to Stephen Bird and T. Bletso of the Bath City Council Museums Service and City Engineer's Department for giving us access to the Roman baths. We thank Crawford Dow for his painstaking determination of $\mathrm{G}+\mathrm{C}$ values. 


\section{LITERATURE CITED}

1. Czurda, V. 1937. Weiterer Beitrag zur Kenntnis der neuen autotrophen und thermophilen Schwefelbakteriengesellschaft. Zentralbl. Bakteriol. Parasitenkd. Infektionskr. Hyg. Abt. 2 96B:138-145.

2. DiSpirito, A. A., W. H.-T. Loh, and O. H. Tuovinen. 1983. A novel method for the isolation of bacterial quinones and its application to appraise the ubiquinone composition of Thiobacillus ferrooxidans. Arch. Microbiol. 135:77-80.

3. Justin, P., and D. P. Kelly. 1978. Metabolic changes in Thiobacillus denitrificans accompanying transition from aerobic to anaerobic growth in continuous chemostat culture. J. Gen. Microbiol. 107:131-137.

4. Katayama-Fujimura, Y., N. Tsuzaki, and H. Kuraishi. 1982. Ubiquinone, fatty acid and DNA base composition determination as a guide to the taxonomy of the genus Thiobacillus. J. Gen. Microbiol. 128:1599-1611.

5. Kelly, D. P., L. A. Chambers, and P. A. Trudinger. 1969. Cyanolysis and spectrophotometric estimation of trithionate in mixture with thiosulfate and tetrathionate. Anal. Chem. 41:898-901.

6. Lu, W.-P., A. P. Wood, and D. P. Kelly. 1983. An enzymatic lysis procedure for the assay of enzymes in Thiobacillus A2. Microbios 38:171-176.

7. Smith, A. L., D. P. Kelly, and A. P. Wood. 1980. Metabolism of Thiobacillus A2 under autotrophic, mixotrophic and heterotrophic conditions in the chemostat. J. Gen. Microbiol. 121:127-138.

8. Tuovinen, O. H., and D. P. Kelly. 1973. Studies on the growth of Thiobacillus ferrooxidans. Arch. Mikrobiol. 88:285-298. 